\title{
Preservice science teachers' informal reasoning and scientific habits of mind: A case of hydroelectric power plants
}

\author{
Burak Kalin (i) \\ Sehit Harun Maytalman Middle School, Ordu, Turkey, burak_kalin17@erdogan.edu.tr \\ Bahadir Namdar ${ }^{\text {(i) }}$ \\ Ege University, İzmir, Turkey, bahanamdar@gmail.com
}

ABSTRACT This study investigates preservice science teachers' informal reasoning and scientific habits of mind about hydroelectric power plants. The sample of the study consists of 587 preservice science teachers who studied in four different universities in the Eastern Black Sea region of Turkey. Data were collected through a questionnaire that consists of four open-ended questions regarding a hydroelectric power plant construction and the scientific habits of mind scale. Content analysis was used to analyze the questionnaire. The same data were then subjected to quantitative descriptive analysis. In the analysis of quantitative data, the Jamovi program was used. Independent samples t-test was used to determine the relationship between scientific habits of mind and informal reasoning. Results indicated that the preservice science teachers mostly used ecological-oriented informal reasoning mode, and counterarguments were the least created argument component. Preservice science teachers' the least used informal reasoning mode was social-oriented. Informal reasoning quality of students with high scientific habits of mind score was found to be high, but no significant difference was found between the total number of informal reasoning modes and scientific habits of mind scores. In line with the results, implications were provided for preservice science teacher education.

Keywords: Informal reasoning, Preservice Science Teachers, Scientific habits of mind, Socioscientific issues

\section{Fen bilgisi öğretmen adaylarının informal muhakemeleri ve bilimsel düşünme alışkanlıkları: Hidroelektrik santraller örneği}

ÖZ Bu çalışma, fen bilgisi öğretmen adaylarının hidroelektrik santraller hakkında informal muhakemelerini ve bilimsel düşünme alışkanlıklarını incelemektedir. Araştırmanın örneklemini Türkiye'nin Doğu Karadeniz bölgesinde dört farklı üniversitede öğrenim gören 587 fen bilgisi öğretmen aday1 oluşturmaktadır. Veriler hidroelektrik santrallerin kurulumu ile ilgili dört adet açı uçlu soru içeren bir anket ve bilimsel düşünme alışkanlıkları ölçeği aracılığıyla toplanmıştır. Anketin analizinde içerik analizi kullanılmıştır. Bilimsel düşünme alışkanlıkları ile informal muhakeme arasındaki ilişkiyi belirlemek için bağımsız örneklemler $t$ testi kullanılmıştır. Sonuçlar, fen bilgisi öğretmen adaylarının en çok ekolojik odaklı informal muhakeme modunu kullandıklarını ve karşıt argümanların en az oluşturulan argüman bileşeni olduğunu göstermiştir. Fen bilgisi öğretmen adayları en az sosyoloji odaklı informal muhakeme modunu kullanmıştır. Bilimsel düșünme alıșkanlığı puanı yüksek olan öğretmen adaylarının informal muhakeme kalitesi yüksek bulunmuş, ancak informal muhakeme biçimleri toplam sayısı ile bilimsel düşünme alışkanlığı puanları arasında anlamlı bir farklılık bulunmamıştır. Sonuçlar doğrultusunda hizmet öncesi fen bilgisi öğretmenliği eğitimine yönelik öneriler verilmiştir.

Anahtar Bilimsel düşünme alışkanlıkları, Fen bilimleri öğretmen adayları, Informal muhakeme, Sosyobilimsel Sözcükler: konular 


\section{INTRODUCTION}

Science education has long been aimed at equipping students with knowledge, skills, and tools to make well-informed decisions about complex issues in daily life (Sakschewski et al., 2014). To engage students in decision-making by considering the moral and ethical aspects of complex issues, socioscientific issue-based teaching has been advocated to be incorporated in school science curricula (Chowdhury, 2016; Sadler \& Zeidler, 2004). Socioscientific issues (SSI), the term coined to explain situations with ties to science and society, provide dilemmatic situations that require individuals to engage in decision-making processes through the use of informal reasoning (Sadler, 2004; Zeidler et al., 2005). Through informal reasoning individuals assess the pros and cons, advantages and disadvantages of an issue when making informed-decision (Means \& Voss, 1996). Making decisions about SSI through informal reasoning requires individuals to engage in discourse and debate.

According to Gauld (2005) individuals who act following scientific methods and have scientific attitudes should have certain characteristics in the process of research, inquiry, and access to scientific information. These characteristics, called scientific habits of mind (SHOM), are open-mindedness (being receptive of new ideas), skepticism (critically examining the information), rationality (reasoning in an informed way), objectivity (reducing idiosyncratic contributions), mistrust of arguments (approaching an argument skeptically due to the status of the arguer), suspension of belief (not rushing to make judgments due to insufficient evidence), and curiosity (being receptive to learn new content) (Gauld, 1982). These are the most critical factors in the process of obtaining scientific knowledge, carrying out the research process in an informed way, reaching scientifically qualified information, and finally making informed decisions (Gauld, 1982; Wiyarsi \& Çalık, 2019).

Based on relevant literature on socioscientific decision-making, Çalık and Coll (2012) identified major components of decision-making as uncertainty, rationality, the trustworthiness of credibility, critical thinking, evidence, asking critical or epistemological questions, open-mindedness, ability to identify bias and reflect critically critical scrutiny, and holding in abeyance. Considering the key features of SHOM identified by Gauld $(1982,2005)$, they concluded that socioscientific decision-making and SHOM overlap in six major categories: open-mindedness, skepticism, rationality, objectivity, mistrust of arguments, and suspension of belief.

Individuals need to go through a reasoning process to make decisions based on arguments (Shaw, 1996). When the dilemmas of SSI and their controversial consequences are considered, informal reasoning comes to mind as the most appropriate form of reasoning. Informal reasoning refers to the process of evaluating positive and negative aspects of a subject, weighing pros and cons, and thus supporting a decision based on justifications (Evans \& Thompson, 2004; Means \& Voss, 1996). In the process of informal reasoning, an individual engages in evidence-based discourse and reaches a decision as a result (Zohar \& Nemet, 2002). For individuals to reason in SSI formally or informally, they must first have knowledge of the subject. Furthermore, to have access to information that is scientifically qualified, individuals must engage in the scientific research process. In this process, the findings and information obtained from the results of the research will be interpreted by the researcher. It can be stated that to carry out the research process in an informed way, to reach scientifically qualified information, and to finally make informed decisions, individuals should possess SHOM (Gauld, 1982). Therefore, SHOM plays an important role in socioscientific decision-making through informal reasoning (Wiyarsi \& Çalık, 2019).

\section{Teacher Preparation Programs in Turkey}

Informal reasoning is the process by which individuals decide by evaluating multiple aspects of the issue in light of the data obtained in the solution of a particular problem, considering the pros and cons and 
taking into account the benefits and disadvantages (Zohar \& Nemet, 2002). Means and Voss (1996) described informal reasoning as a purposeful process that involves producing evidence or generalizing a claim or result. Sadler (2004) describes the relationship between SSI, informal reasoning, and argumentation as in the following: SSI are solved by informal reasoning, and informal reasoning is explained by argumentation. In the process of informal reasoning, an individual creates multiple arguments on the subject and performs any number of arguments about these arguments. As a result of reasoning, an individual decides one of these arguments. Thus, the process of informal reasoning is solved by using argumentation (Wu \& Tsai, 2007).

In the literature, informal reasoning is characterized by different perspectives such as reasoning patterns and reasoning modes (Patronis et al., 1999; Sadler \& Zeidler, 2005). Some other researchers investigated informal reasoning qualities. To determine the quality, researchers often use argumentation quality as an indicator. However, there is no linear relationship between informal reasoning and argumentation. Individuals with high-quality informal reasoning can have a high-quality argument, and high-quality informal reasoning can be expressed with low-quality arguments (Means \& Voss, 1996). In their study, Wu and Tsai (2007) offered a holistic framework to capture high school students' informal reasoning on nuclear energy. Their assessment included three stages: (a) decision-making mode and position change: as intuitive or evidence-based and the position remained or changed, (b) informal reasoning modes: social, economy, ecology, and science or technology-oriented modes, and (c) reasoning quality: number of supporting arguments, number of counter-arguments, and number of rebuttals.

Most studies have investigated school-age students' informal reasoning but research on preservice teachers' informal reasoning was relatively less studied. For instance, Ladachart and Ladachart (2021) investigated Thai preservice biology teachers' informal reasoning about two different culture-based SSI. They found that preservice teachers considered issues from different multiple perspective and their reasoning was differed based on the cultural and religious relevancy and the importance of the issue. However, most studies investigating preservice science teachers' informal reasoning were conducted in Turkey (Nielsen, 2020). For example, Ozturk and Yilmaz-Tuzun (2017) investigated the relationship between 657 preservice science teachers' informal reasoning and epistemological understandings on nuclear energy topic. They found that preservice science teachers mostly created supportive arguments, and used risk-oriented and political-oriented informal reasoning modes as different from what other studies reported. Evren Yapıcıoğlu and Aycan (2018) investigated the effect of an intervention on preservice science teachers' positions and informal reasoning about nuclear energy. They found that most used reasoning modes changed to social-oriented from ecology-oriented, and preservice teachers changed their positions about the issue. In another study Pehlivanlar (2019) investigated a total of 376 preservice science and elementary teachers' informal reasoning about local, national, and global SSI. Results indicated that the participants used different informal reasoning modes in different SSI contexts and they mostly created supportive arguments compared to rebuttals and counterarguments. Namdar et al. (2020) investigated the effect of preservice science teachers' attitudes towards SSI and media literacy on informal reasoning about hydroelectric power plants (HePP). They found that the participants most frequently used ecology-oriented reasoning, created supportive arguments, perceived level of media literacy levels predicted reasoning quality and modes, but attitudes towards SSI did not predict informal reasoning. In a more recent study Cebesoy (2021) investigated eleven preservice science teachers' informal reasoning and risk perceptions on gene therapy subject. They found that preservice teachers used one or more informal reasoning patterns. In their study with 26 preservice biology teachers, HanTosunoglu and Ozer (2021) found that preservice teachers mostly made rationalistic decisions and considered risk perceptions about Covid 19 and social isolation. Karisan and Cebesoy (2021) indicated that several factors such as science, ethics, economy, politics, and culture affect preservice science teachers' informal reasoning about gene therapy and preimplantation genetic diagnosis subjects. Overall, these studies indicated that informal reasoning modes were context-dependent, instruction influenced decisions and the use of reasoning modes, preservice teachers mostly created supportive arguments about SSI, epistemological beliefs, attitudes, and media literacy was investigated as predictors. However, some studies indicated that preservice teachers had difficulties in reasoning from multiple aspects of SSI and did not have adequate informal reasoning skills (Eş \& Varol, 2019). 


\section{Scientific Habits of Mind (SHOM)}

In the process of informal reasoning, it is necessary to use some research processes to reach qualified scientific information. The approaches used by individuals in this process and their preferred scientific methods express their scientific attitudes (Gauld, 1982). In this sense, a scientific attitude is a competence that needs to be supported and developed for high-quality decision-making (Çalık \& Coll, 2012). Individuals who have a scientific attitude are individuals who are willing to prefer scientific methods in research to access the scientific information.

When the habits of mind are examined, it can be assumed that the features are merely the competencies that scientists should possess. However, when individuals need to make decisions about a problem they may face in daily life or on dilemma matters concerning themselves and their society in which they live, SHOM comes along as one of the fundamental skills (Çalık \& Coll, 2012; Gauld, 1982). In the context of SSI-based teaching and learning, SHOM is important to understand and mimic how scientists think and practice their work (Çalık \& Coll, 2012). To make objective and rational decisions by making effective use of reasoning processes, it is necessary to have SHOM specific to scientific attitude.

There has been a limited number of studies on SHOM in the context of SSI that was conducted with preservice teachers. These studies investigated the comparison of elementary preservice teachers' SHOM based on the participants' field of study (Çalık et al., 2014), the effect of common knowledge construction model on preservice elementary teachers' SHOM (Çalık \& Cobern, 2017), preservice science teacher' SHOM related to environmental problems (Güven, 2017), and the effect of a science, technology and social change course on preservice science teachers' SHOM and attitudes towards SSI (Çalık \& Karataş, 2019). Çalık and Coll (2012), based on relevant literature, argued that decisionmaking and argumentation about SSI involve the features of open-mindedness, rationality, objectivity, skepticism, suspension of belief, and mistrust of arguments from authority. Therefore, it can be concluded that there is a significant overlap between decision-making and SHOM. As we characterize decision-making in the context of SSI through informal reasoning, the connection between informal reasoning and SHOM is inherent. However, this interpretation needs further empirical evidence. Although theoretical connections are made between SHOM and SSI decision-making, as to our knowledge, none of the studies investigated the relationship between SHOM and informal reasoning about SSI. Identifying this relationship is important to design and implement scaffolds in science teacher education for informed SSI-based decision-making. Therefore, the current study is unique to identify the relationship between SHOM and informal reasoning.

\section{Purpose of the Study}

Although the connection between informal reasoning and SHOM, specifically in the context of SSI, is well articulated theoretically (c.f. Çalık \& Coll, 2012; Çalık \& Karataş, 2019) and highlighted in the curriculum (Ministry of National Education [MoNE], 2018), there is a gap in the literature that relationship between informal reasoning and SHOM are not empirically tested. This becomes particularly important in the context of science teacher education as teachers can affect students' decision-making on SSI (Çetin et al., 2014). Thus, meaningful courses, contexts, and scaffolds could be provided for informed SSI decision-making (Topçu et al., 2011) concerning SHOM. The aim of this study is to investigate preservice teachers' informal reasoning and SHOM and the relationship between these two constructs, in the context of hydroelectric power plant issue. With this regard, we investigated the following research questions in our inquiry:

i. What type of informal reasoning modes do preservice science teachers use in their informal reasoning about hydroelectric power plants?

ii. What is the quality of the preservice science teachers' informal reasoning regarding hydroelectric power plants?

iii. What is the relationship between SHOM and informal reasoning quality? 


\section{METHODS}

The descriptive research method was used in the study (Nassaji, 2015). In contrast to qualitative research, in descriptive research, instead of the examination of why or how a case is, what is a case is investigated. In this type of research, measurement tools are generally used for survey purposes. In addition to the use of scales, which are generally quantitative measurement tools, qualitative data can be collected in such studies. Qualitative data can then be analyzed quantitatively (Nassaji, 2015). In this descriptive research, qualitative and quantitative data collection tools were used together. Qualitative data were first analyzed by using content analysis. The same data were then subjected to quantitative descriptive analysis. Then, the relationship between these descriptive data and quantitative measurement tools was analyzed quantitatively. Using both quantitative and qualitative measures is important to better understand the informal reasoning of preservice science teachers.

\section{Study Group}

The study was carried out with 587 preservice science teachers aged 18-30 years who were enrolled in science teacher education programs at four different universities located in the north-eastern Turkey in 2018-2019 academic year. Institutional review and ethics board approval from Artvin Çoruh University (Date: 26.12.2018-No:2018/12-2) and consent forms from the participants were obtained. Preservice science teachers, who graduate from the undergraduate programs, work as middle school science teachers. Descriptive statistics of the sample group are given in Table 1.

Table 1.

Number of Participants by University and Gender

\begin{tabular}{lccc}
\hline University & Female & Male & Total \\
\hline A & 84 & 28 & 112 \\
B & 54 & 18 & 72 \\
C & 103 & 34 & 137 \\
D & 229 & 37 & 266 \\
Total & 470 & 117 & 587 \\
\hline
\end{tabular}

\section{Hydroelectric Power Plant Issue}

HePP in the Black Sea Region of Turkey is one of the highly debated SSI in local and national media as there is an increasing number of HePP construction in the area. As there is a call for selecting local SSI for meaningful engagement in discussions about these issues, there is an increasing number of studies about the effects of the context of the issues in informal reasoning (Atasoy, 2018; Cian, 2020; Pehlivanlar, 2019), we chose the participants whose universities were located in the top four provinces in terms of the number of HePP in the Eastern Black Sea Region (Gökdemir et al., 2012). While 360 participants supported the construction of power plants, 229 were against it. A total of 491 participants reported that they would make their decision by considering the evidence regarding the issue, while 96 reported that they would make their decisions based on their intuitions.

\section{Data Collection}

Two data collection tools were used in this study. In the first part, an open-ended questionnaire developed by the researchers about the HePP was used to investigate informal reasoning (Appendix A). The main text of the HePP questionnaire consists of two parts. In the first part, the definition of HePP, which is widely used in the literature, is provided, and its working principle is mentioned. In the rest of the text, positive and negative criticisms of the public about HePP were provided similar to previous studies (Wu \& Tsai, 2007; Ozturk \& Yilmaz-Tuzun, 2017). While writing the scenario text, equal attention was paid to the positive and negative aspects of the subject. Similarly, equal weight was given 
to distribute justifications in equal informal reasoning modes.

The second part of the questionnaire consisted of four open-ended questions to reveal the informal reasoning of the participants. In the first question, the participants were asked whether they agree with the idea of building a HePP in the city where they study and the reasons for this idea. In the second question, the participants were asked what other reasons they would provide to convince another person. The third question asked about what views a person who opposes him/her can put forward. In the last question, the participant was asked how to refute the contradictory claims stated in the previous question and on what data and reasons would he defends his own opinion. The scenario was based on similar forms that were frequently used in the literature and were prepared to determine the informal reasoning of students and teachers (e.g. Ozturk \& Yilmaz-Tuzun, 2017). Two science education faculty members reviewed the form. The scenario was also applied to 5 pre-service teachers. Based on their opinions about the text and feedback received from the experts, the scenario was grammatically corrected, detailed scientific information about the HePP working mechanism was deleted, and a question about whether they support the establishment of HePP in the city that they were studying was added.

In the second part of the study, "Scientific Habits of Mind Scale," consisting of a 32-item self-report measure developed by Çalık and Coll (2012) was used after getting a permission from the author. Likert scale responses ranged from 1 to 4 (always true, maybe true, maybe wrong, always wrong). Çalık and Coll (2012) ensured the validity of the scale by defining a theoretical framework, using panel of experts for face validity, interviewing teachers, lay people and preservice teachers for readability and item comprehension, conducting comfirmatory factor analysis and convergent and discriminant validity. In the current research, the Cronbach alpha reliability value of the scale was 0.657 . Similar results were found in previous studies conducted with Turkish preservice teachers (Çalık \& Karataş, 2019; Güven, 2017). The first author reviewed the science education program schedules of the universities. Then, he contacted the course instructors and arranged a data collection time during or after the instructors' scheduled courses. The first author administered the data collection tools face-to-face in the classes, in a paper-pencil format. Each participant was given both the questionnaire and the scale. It took around 40 minutes to fill in the data collection tools by a participant. All necessary permissions were obtained from the participating universities.

When the relationship between informal reasoning quality and SHOM was examined, the informal reasoning quality of the high $\mathrm{SHOM}$ group $(\mathrm{M}=8.92, \mathrm{SD}=3.93)$ was higher than the low SHOM group $(\mathrm{M}=8.12, \mathrm{SD}=4.05)$. Levene test results were not significant. Therefore, the variances of the groups were different. Skewness and kurtosis values for informal reasoning modes and quality scores were found between -1.5 and + 1.6, indicating a normal distribution (Tabachnick \& Fidell, 2013).

\section{Data Analysis}

To analyze the questionnaire, descriptive analysis method was used (Yıldırım \& Şimşek, 2006). Participants' answers to the questions to reveal their quality of informal reasoning were examined. The number of valid reasons used to support their answers was coded and counted. Initial arguments referred to the arguments put forward by the preservice teachers before they make personal position about the hydroelectric power plant issues. Supportive arguments are the valid justifications that further support preservice teachers' positions about the issue. Counterarguments are the arguments that are against the preservice teachers' personal positions about the issue. Rebuttals are the claims that the prior arguments are not valid or true. The number of initial arguments, supportive arguments, counterarguments and rebuttals were obtained from the questions provided in the scenario (see Appendix) respectively. Furthermore, the answers given to the questions to determine informal reasoning modes were analyzed by using content analysis. It was determined how many different points of view the participant benefited from during the justification of the answers and what these perspectives were.

For the reliability of the analysis, the first 50 questionnaire forms were coded separately by the researchers. The reliability coefficient between the coders was calculated (Miles \& Huberman, 1994) as 
.96 for the quality of informal reasoning, .88 for the informal reasoning modes of the first question, and .90 for the second question. Then the coders came together to discuss the disputes. The rest of the coding was completed by the first author.

In the analysis of quantitative data, the Jamovi program was used (Jamovi Project, 2019). First, the Cronbach's alpha reliability coefficient of the scale was calculated. Then two groups, SHOM-high and SHOM-low, were determined based on the total score obtained from the SHOM scale. We identified the total SHOM average score of 2.5 (which is the mid-point) and above as SHOM high, and below 2.5 as SHOM-low. The necessary kurtosis and skewness values were calculated for normality values. Independent samples t-test was used to determine the relationship between SHOM and informal reasoning modes, and SHOM and informal reasoning quality.

\section{FINDINGS}

\section{Informal Reasoning Modes}

Informal reasoning modes were coded by examining the answers of the participants to the questions in the questionnaire. We identified 5 informal reasoning modes as ecology, scientific/technological, economic, political, and social-oriented. Looking at the variety of arguments used by preservice teachers in the whole informal reasoning process, we found that $65 \%$ of the group used three or more informal reasoning modes in the informal reasoning process. Furthermore, out of 587 pre-service teachers, 543 (92\%) performed their informal reasoning using multiple reasoning modes.

In the questionnaire, the number of valid reasons stated in each question revealed the participants' reasoning about HePP. We first identified the number of valid and unique justifications provided by the participants under each reasoning mode for the questions. Then we added these numbers. Later, we calculated the mean and standard deviation for each reasoning mode. The total number of informal reasoning modes used in the answers given to these questions is given in Figure 1. Also, valid justifications used in each informal reasoning mode ranged from 0 to 6.

\section{Figure 1.}

Total Number Justifications Used in Each Informal Reasoning Mode

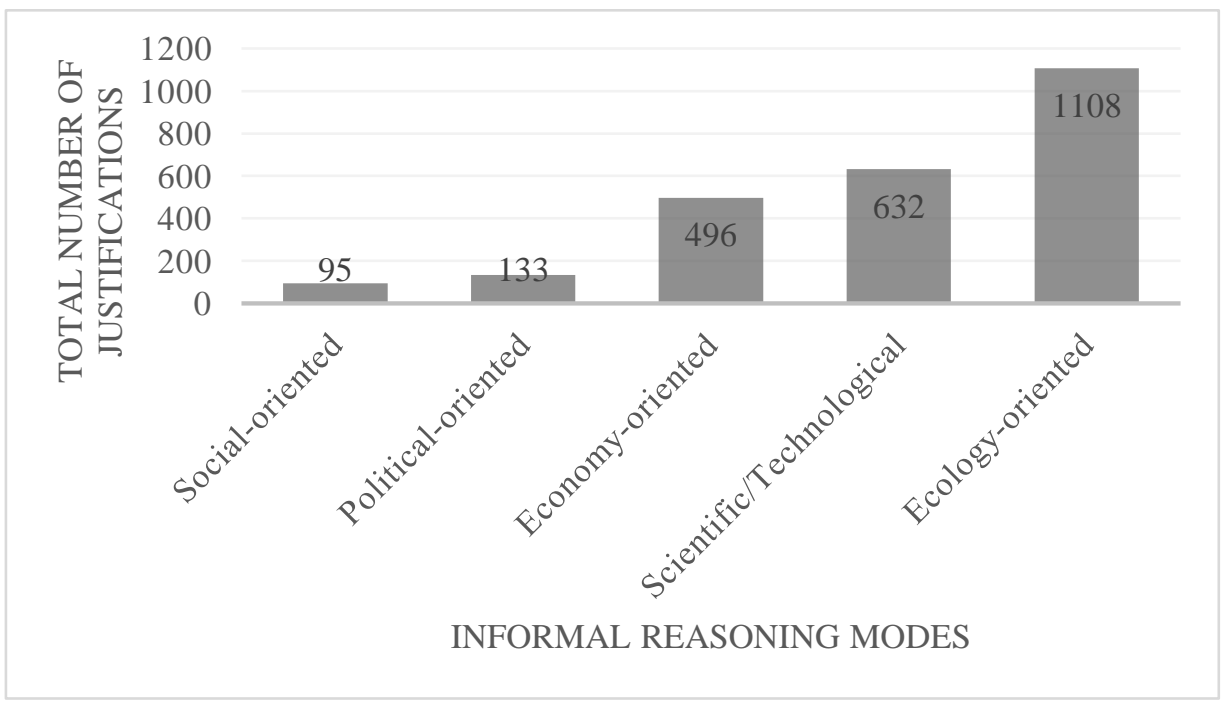

Table 2 indicated that on average the participants used around two ecology-oriented justifications $(\mathrm{M}=2.04, \mathrm{SD}=1.72)$ in their reasoning, which is followed by scientific/technological-oriented reasoning 
modes $(\mathrm{M}=1.95, \mathrm{SD}=1.76)$. The least used informal reasoning mode was social-oriented $(\mathrm{M}=0.32, \mathrm{SD}=$ $0.72)$.

Table 2.

Mean Scores Across Informal Reasoning Modes

\begin{tabular}{lcl}
\hline Reasoning Mode & Mean & $S D$ \\
\hline Social-oriented & 0.32 & 0.72 \\
Political-oriented & 0.37 & 0.81 \\
Economy-oriented & 1.47 & 1.51 \\
Scientific/Technological-oriented & 1.95 & 1.76 \\
Ecology-oriented & 2.04 & 1.72 \\
\hline
\end{tabular}

As expected, the primary reasoning mode was ecology-oriented. The participants' reasoning included justifications that reflected mostly their concerns about the environment. These justifications included HePP's effect on the living things in rivers, the vegetation on the riverbeds, changes in climate patterns, and the effect on fauna and flora as well as endemic species. Some participants also stated HePP protects nature by preventing pollution in the river.

PST 243: In the stream bed, we can say that there is no waste. Also, when they collect the water before it goes to the tribunes, all the waste and garbage are held there. Therefore, it is beneficial for the environment."

PST 476: HePP will have negative effects on the fish ecosystem. Also, while the HEPP [hydroelectric power plant] studies are carried out, the natural environment is destroyed due to the concrete used to build the plant that surrounds the streams. Eliminating plant species is another drawback."

The second-most used informal reasoning mode is scientific-technological. These justifications included the clean energy production process, development in the energy industry and technology, and scientific and technological development regarding the safety of the plants and their working mechanisms.

PST 198: “...considering the population and needs, there is a need for electrical energy. The depletion of energy resources has led to the search for new energy methods that are renewable and do not harm the air. The hydroelectric power plant should be established because it provides clean energy production. Because the steady water first has potential energy, when they release the water, the running water kinetic energy turns the turbines, and it produces electricity. There are no byproducts whatsoever."

Economy-oriented informal reasoning was the third most-used informal reasoning mode. This reasoning mode included economic benefits and hence the development of the country, contribution to the local economy, providing employment, and affecting agriculture and animal husbandry. These statements were generally about the benefits of constructing power plants in the region.

PST 204: "I agree because this city definitely needs improvement. Hydroelectric power is a nice economic resource. Also, our province is very rich in water. It must be evaluated ..."

PST 331: "I think we have to sacrifice things to make a profit. Or we should profit with minimal damage. One of these ways is hydroelectric power, in my opinion."

Political-oriented informal reasoning mode included geopolitical importance of the country, localization of income sources, reducing external dependence, and government policies.

PST 481: "The world is entering the age of energy and technology. These projects should be carried out to become one of the top 10 economies and reduce external energy dependency. These projects can enable us to use energy at a low price." 
PST 48: "To strengthen economically, we have to get rid of external dependence. We must produce our energy."

The social-oriented informal reasoning mode was the least used. The justification in this mode included the impact on human life and human-environment interaction, expropriation, forced migration, and sociocultural characteristics of the region.

PST 485: For people forced to migrate [because of HePP construction], they can settle elsewhere. A man residing in our apartment and taking a duplex apartment from the construction company is a perfect example. His land was in a place where a bird never flew. The land was highly valued after the power plant is decided to be constructed."

PST 201: "I do not agree because I think it is a small city, and the proximity of the power plant to the settlement is disturbing. It is not suitable for a power plant. After the consent of the public, the installation and start of the power plants will be difficult, and it will be restrictive for people while searching for a place for the power plant."

\section{Informal Reasoning Quality}

Table 3 reports the distribution of the mean and standard deviation scores across four questions presented in the questionnaire. Results revealed that the highest number of justifications are provided for supporting arguments. The number of counter-arguments provided by the participants was the least. However, the preservice teachers were able to create more than one justifications for each of the argument components.

Table 3.

Preservice Teachers' Informal Reasoning Qualities Across Argument Components

\begin{tabular}{lcc}
\hline Question & $M$ & $S D$ \\
\hline 1 (Initial arguments) & 1.95 & 1.28 \\
2 (Supportive arguments) & 2.26 & 1.55 \\
3 (Counter-arguments) & 1.86 & 1.17 \\
4 (Rebuttals) & 2.25 & 1.77 \\
\hline
\end{tabular}

\section{The Relationship Between Scientific Habits of Mind (SHOM) and Informal Reasoning}

When the habits of mind were examined, the students with a total average score of 2.5 above the average point of habits of mind were classified as high in habits of mind, and the lower ones were classified as low in habits of mind. The results showed that 174 pre-service teachers had high SHOM scores, and 413 had low SHOM scores.

There was a significant difference between the average scores of informal reasoning quality scores of the group with high habits of mind and those with low habits of mind scores $(p<0.05)$. Table 4 shows that the group with high SHOM scores had higher scores in terms of informal reasoning quality $(\mathrm{M}=$ 8.92, $\mathrm{SD}=3.93$ ). Accordingly, the informal reasoning quality of the group with high SHOM was high.

\section{Table 4.}

Informal Reasoning Quality and Mode Independent Samples t-test

\begin{tabular}{lllllll}
\hline Informal reasoning & SHOM & $n$ & $M$ & $S D$ & $t$ & $p$ \\
\hline Quality & High & 174 & 8.92 & 3.93 & 2.21 & $.03^{*}$ \\
& Low & 413 & 8.12 & 4.05 & & \\
Mode & High & 174 & 2.88 & .95 & .64 & .52 \\
& Low & 413 & 2.82 & 1.04 & & \\
\hline (*p<.05) & & & & & &
\end{tabular}

However, there was no significant difference between the average informal reasoning mode scores of 
the group with high SHOM and the group with low SHOM scores ( $p>0.05)$. According to this result, it can be said that there was no statistically significant relationship between preservice teachers' SHOM and informal reasoning modes $(t=0.64, \mathrm{p}>0.05)$.

\section{DISCUSSION AND CONCLUSION}

\section{Discussion Regarding Informal Reasoning Modes}

Results indicated that preservice teachers mostly used ecological-oriented informal reasoning about $\mathrm{HePP}$. This finding was consistent across several studies focusing on informal reasoning about HePP in the Black Sea region (e.g. Atasoy, 2018; Pehlivanlar, 2019) as well as non-localized energy-related SSI (Ozturk \& Yilmaz-Tuzun, 2017). Well-established research concludes that reasoning is contextdependent (Cian, 2020; Topçu et al., 2010). Our findings further contribute to this body of research that some SSI contexts might be better suited for externalizing a particular mode of informal reasoning. In this specific context, this result could be explained by individuals' ecological concerns. Previous research found that the local people stated that HePP constructions should be banned due to the negative effects on the natural environment (Öztürk \& Leblebicioğlu, 2015), and preservice teachers were against the construction of HePP due to their negative effects on fisheries and their damages to nature (Yangin et al., 2012).

The preservice teachers' second-most used reasoning mode was scientific or technological-oriented. Contradictory results are present in the literature in the context of different energy-related SSIs. Several studies explain the inadequate use of scientific or technological-oriented reasoning due to the relevance of issues to students' lives. For example, in a study conducted with preservice teachers and examining their informal reasoning about nuclear energy, it was determined that preservice teachers used this reasoning mode at least. Researchers have already explained the reasons for this situation in Turkey as the absence of nuclear power plants and therefore, preservice science teachers' inadequate scientific knowledge on the issue (Ozturk \& Yilmaz-Tuzun, 2017). Considering that the nuclear energy issue is still at a larger scale than hydroelectric power, choosing a topic of interest to the region may have caused the participants to become familiar with the scientific and technological aspects of these issues. Another difference exists between school students (Wu \& Tsai, 2007) and preservice teachers in the use of scientific-technological-oriented reasoning. After science education training preservice teachers might have increased their abilities to make connections between what they have learned and what they have encountered in daily life.

The social-oriented reasoning mode is the least repetitive mode of informal reasoning. The low level of social-oriented informal reasoning mode was also found in studies conducted with high school students (Wu \& Tsai, 2007), university students (Wu, 2013), and preservice teachers (Atasoy, 2018). When this result is examined, it can be seen that preservice teachers provide a limited number of arguments about the social effects of HePP. Although the social and sociocultural structure of the city in which the preservice teachers studied is influential in the decision-making process, it can be thought that the preservice teachers do not express this connection in their reasoning processes.

\section{Discussion Regarding Informal Reasoning Quality}

When the types of reasoning modes used by preservice science teachers are examined, it is seen that most of them tend to use multiple informal reasoning modes. Wu and Tsai (2007) suggest that multiple reasoning modes could provide better contexts for rebuttal construction. However, our results showed that the number of supporting arguments was higher than the number of rebuttals and counter-arguments (Table 3). In the literature, it is stated that students face difficulties in creating counterclaims and rebuttals, especially in written arguments (Leitão, 2003). The high number of supportive arguments might have been seen as a result of the efforts of the preservice science teachers to diversify the data 
sources to have their opinions to be accepted. In the literature, one of the most serious difficulties that students face in the argumentation process is that they take into consideration the data that support their claims and ignore the opposite ideas and data (Sampson et al., 2013). This was still evident even after science teacher education training that preservice teachers used multiple perspectives to support their initial ideas rather than posing counterarguments and rebuttals.

\section{Discussion Regarding Informal Reasoning Quality}

Results indicated that preservice science teachers with high SHOM scores were able to produce highquality informal reasoning about HePP. This result is important as we provide empirical evidence suggesting a connection between high-quality informal reasoning and high SHOM scores. This result could be explained by the nature of SHOM, which is a set of skills that comprise a scientific attitude. As Gauld (1982) asserted, decisions cannot be made solely based on the claims of authority, but they should be approached skeptically and judged by available evidence. This process overlaps with the informal reasoning process for informed decision-making, which includes weighing evidence for constructing a sound argument for solving a complex issue (Means \& Voss, 1996).

Elby and Hammer (2001) note that learners should develop epistemological resources to question and critique information when they come from an authority. In another words, they call for an epistemological sophistication by which learners evaluate the trustworthiness of information. In the case of SSI, epistemological sophistication might be a crucial tool for reasoning to evaluate available arguments, which leads to high quality reasoning. Epistemologically sophisticated learners are expected to mistrust the arguments from authority and skeptically approach information in their reasoning processes (Çalık \& Coll, 2012; Kolstø, 2001). Our study illustrated the connection between high SHOM and high informal reasoning.

However, our findings also illustrated that the majority of the preservice science teachers had low SHOM scores. This finding is inconsistent with that of Güven (2017), who identified high SHOM of preservice science teachers. One reason for such inconsistency might be attributed to the scales used to identify SHOM. In their study Güven (2017) developed a specific scale (namely Eco-Scientific Habit of Mind Scale) to identify preservice science teachers' SHOM on environment related problems. Therefore, this finding may be explained by the idea that SHOM scales might be adapted to different SSI contexts to better identify SHOM (Wiyasi \& Çalık, 2019).

One of the reasons for low SHOM scores with low informal reasoning quality might be due to not being able to consider alternative explanations when reasoning about complex SSI. A recent study indicates that preservice teachers are less open-minded about SSI than expected even after instruction, which is identified by the SHOM open-mindedness' sub-scale (Çalık \& Karataş, 2019). This could lead to preservice teachers not being open to new and alternative ideas. In turn, preservice teachers might reason the issue from a single perspective and this could lower their informal reasoning quality scores (c.f. Ozturk \& Yilmaz-Tuzun, 2019). This is also consistent with current research reporting that considering alternative perspectives leads to high quality informal reasoning through higher number of justifications provided in different components of an argument (Pehlivanlar, 2019). On the other hand, by simply considering the issue from a single perspective could lower the number of informal reasoning modes used in reasoning a given SSI.

Preservice teachers with high SHOM are expected to use critical inquiry and examine SSI from different aspects. However, it was seen that high-quality SHOM does not always guarantee reasoning that incorporates a higher number of reasoning modes. The possible interpretation of this result could be due to the nature of the SSI chosen. Although the HePP issue is complex and involves multifaceted perspectives, similar to other studies, individuals tend to discuss such environmental issues from an ecological perspective (Gayford, 2002). Therefore, it becomes important to increase integrative thinking skills (Hogan, 2002), so that preservice teachers could reflect their high SHOM to their multifaceted arguments (Liu et al., 2011). 


\section{Implications \& Future Research Directions}

One of the prerequisites for constructing counterarguments and rebuttals is having analytical thinking skills. In this way, preservice teachers will be able to think multi-dimensionally and evaluate the issues from different perspectives. The use of teaching techniques that support multi-dimensional thinking skills in teacher education programs will contribute to the development of these skills. For example, through techniques that allow individuals to be exposed to multiple perspectives such as role-plays (Simonneaux, 2001) and using computer-assisted collaborative learning scripts (Stegmann et al., 2011), preservice teachers may be able to reason and develop multi-dimensional thinking skills when reasoning about SSI.

The fact that preservice science teachers use social-oriented reasoning mode the least in the informal reasoning process may indicate that they do not have enough identification with the province and the society where they are educated or located. In an increasingly individualized world, strengthening the ties of the preservice teachers with society is vital. In fact, as recent conceptualizations of scientific literacy call for increasing characters and values that would educate students as 21st-century global citizens (Choi et al., 2011), teacher education programs could aim at increasing preservice teachers' agency towards local SSI. This could be achieved through bridging school and society by concentrating on the problems and demands of local people and cooperating with non-governmental organizations in the region within the scope of community service practices.

Skepticism is a subcomponent of SHOM and also informal reasoning about SSI (Kolstø, 2001; Sadler et al., 2007). To increase the use of counter-arguments and thus improve the quality of informal reasoning, preservice teachers should be taught to be skeptical in information search. We suggest implementing media literacy education in the context of socioscientific issue teaching because media literacy includes assessing conflicting views and trustworthiness of data sources to increase SHOM (Dani et al., 2010; Klosterman et al., 2012).

In this study, we investigated the relationship between SHOM and informal reasoning. We chose a local socioscientific issue as these issues could be more relevant to reasoners' lives, and reasoners could potentially have first-hand experiences and knowledge about the issue. As informal reasoning is contextdependent (Atasoy et al., 2019), future studies could focus on identifying this relationship in different contexts. Second, our analysis to informal reasoning modes and qualities analyzed written responses from a specific point of view. For instance, in our analysis we used scientific/technological oriented reasoning mode as a single construct. Future studies could use more fine-grained analysis rubrics to identify preservice teachers' informal reasoning. Third, our inquiry only focused on the quality of preservice science teachers' SHOM instead of investigating how SHOM factors predict informal reasoning. Therefore, future studies could investigate such a relationship. Fourth, the scale we used had questions regarding different SSI. SHOM scales for a specific socioscientific issue context could be developed and validated.

\section{Acknowledgement}

This paper is based on the first author's master's thesis, completed under the direction of the second author.

\section{REFERENCES}

Atasoy, Ş. (2018). Öğretmen adaylarının yaşam alanlarına göre yerel sosyobilimsel konularla ilgili informal muhakemeleri. Fen Bilimleri Ögretimi Dergisi, 6(1), 60-72. 
Atasoy, Ş., Tekbiyik, A., \& Yüca, O. Ş. (2019). Determining informal reasoning of students for some local socioscientific issues in the Black Sea region: HEPP, organic tea and green road project. Hacettepe University Journal of Education, 34(2), 524-540. https://doi.org/10.16986/HUJE.2018045573

Cebesoy, U. B. (2021). Pre-service science teachers' informal reasoning patterns and risk perceptions in SSI: Case of gene therapy. European Journal of Science and Mathematics Education, 9(4), 211-229. https://doi.org/10.30935/SCIMATH/11237

Çalık, M., \& Cobern, W. M. (2017). A cross-cultural study of CKCM efficacy in an undergraduate chemistry classroom. Chemistry Education Research and Practice, 18(4), 691-709.

Çalık, M., \& Coll, R. K. (2012). Investigating socioscientific issues via scientific habits of mind: Development and validation of the scientific habits of mind survey. International Journal of Science Education, 34(12), 1909-1930. https://doi.org/10.1080/09500693.2012.685197

Çalık, M., \& Karataş, F. Ö. (2019). Does a "Science, Technology and Social Change" course improve scientific habits of mind and attitudes towards socioscientific issues? Australian Journal of Teacher Education, 44(6), 34-52. https://doi.org/10.14221/ajte.2018v44n6.3

Çalık, M., Turan, B., \& Coll, R. K. (2014). A cross-age study of elementary student teachers' scientific habits of mind concerning socioscientific issues. International Journal of Science and Mathematics Education, 12(6), 1315-1340. https://doi.org/10.1007/s10763-013-9458-0

Çetin, P. S., Dogan, N., \& Kutluca, A. (2014). The quality of pre-service science teachers' argumentation: influence of content knowledge. Journal of Science Teacher Education, 25(3), 309-331.

Choi, K., Lee, H., Shin, N., Kim, S., \& Krajcik, J. (2011). Re-conceptualization of scientific literacy in South Korea for the 21st Century. Journal of Research in Science Teaching, 48(6), 670-679.

Chowdhury, M. (2016). Emphasizing morals, values, ethics, and character education in science education and science teaching. Malaysian Online Journal of Educational Sciences, 4(2), 1-16.

Dani, D., Wan, G., \& Henning, J. E. (2010). A case for media literacy in the context of socioscientific issues. New Horizons in Education, 58(3), 85.

Elby, A., \& Hammer, D. (2001). On the substance of a sophisticated epistemology. Science Education, 85(5), 554567. https://doi.org/10.1002/sce.1023

Eş, H., \& Varol, V. (2019). Fen bilgisi öğretmenliği ve İlahiyat öğrencilerinin nükleer santral sosyo-bilimsel konusuyla ilgili informal argümanları [The informal argumentation of theology and science education students about the socio-scientific issue: Nuclear power plant]. Mersin Üniversitesi Eğitim Fakültesi Dergisi, 15(2), 437-454. https://doi.org/10.17860/mersinefd.533013

Evans, J. S. B. T., \& Thompson, V. a. (2004). Informal reasoning: theory and method. Canadian Journal of Experimental Psychology, 58(2), 69-74. https://doi.org/10.1037/h0085797

Gayford, C., 2002, Controversial environmental issues: a case study for the professional development of science teachers. International Journal of Science Education, 24 (11).1191-1200

Gauld, C. F. (1982). The scientific attitude and science education: A critical reappraisal. Science Education, 66(1), $109-121$.

Gauld, C. F. (2005). Habits of mind, scholarship and decision making in science and religion. Science \& Education, 14(3-5), 291-308.

Gökdemir, M., Kömürcü, M. İ., \& Evcimen, T. U. (2012). Türkiye'de hidroelektrik enerji ve HES uygulamalarına genel bakış [Hydroelectric energy in Turkey and general view on hydroelectric power plant applications]. In $\quad \dot{I M O} \mathrm{Su} \quad$ Yaplarl $\quad$ Kurulu. http://www.imo.org.tr/resimler/dosya_ekler/d8c5e9986a1c41b_ek.pdf?dergi=260

Güven, O. (2017). Fen bilgisi öğretmen adaylarının çevre problemlerine yönelik bilimsel düşünme alışkanlıklarının incelenmesi [Investigation of scientific habits of mind of pre-service science teachers related to environmental problems]. (Unpublished master's thesis). Karadeniz Teknik University.

Han-Tosunoglu, C., \& Ozer, F. (2021). Exploring Pre-service Biology Teachers' Informal Reasoning and Decision-Making About COVID-19. In Science and Education (Issue 0123456789). Springer Netherlands. https://doi.org/10.1007/s11191-021-00272-5

Hogan, K. (2002). Small groups' ecological reasoning while making an environmental management decision. Journal of Research in Science Teaching, 39(4), 341-368. https://doi.org/10.1002/tea.10025

Karisan, D., \& Cebesoy, U. B. (2021). Use of the SEE-SEP model in pre-service science teacher education: The case of genetics dilemmas. In W. A. Powell (Ed.). Socioscientific issues-based instruction for scientific literacy development (pp. 223-254). IGI Global. https://doi.org/10.4018/978-1-7998-4558-4.ch008

Klosterman, M. L., Sadler, T. D., \& Brown, J. (2012). Science teachers' use of mass media to address socioscientific and sustainability issues. Research in Science Education, 42(1), 51-74. https://doi.org/10.1007/s11165-011-9256-z

Kolstø, S. D. (2001). 'To trust or not to trust ...': Pupils' ways of judging information encountered in a socioscientific issue. International Journal of Science Education, 23, 877-901. 
Ladachart, L., \& Ladachart, L. (2021). Preservice biology teachers' decision-making and informal reasoning about culture-based socioscientific issues. International Journal of Science Education, 43(5), 641-671, DOI: $10.1080 / 09500693.2021 .1876958$

Leitão, S. (2003). Evaluating and selecting counterarguments. Written Communication, 20(3), 269-306.

Liu, S. Y., Lin, C. S., \& Tsai, C. C. (2011). College students' scientific epistemological views and thinking patterns in socioscientific decision making. Science Education, 95(3), 497-517. https://doi.org/10.1002/sce.20422

Means, M. L., \& Voss, J. F. (1996). Who reasons well? Two studies of informal reasoning among children of different grade, ability, and knowledge levels. Cognition and Instruction, 14(2), 139-178. https://doi.org/10.1207/s1532690xci1402_1

Miles, M. B., \& Huberman, M. A. (1994). Qualitative data analysis: An expanded source book. Sage.

Namdar, B., Aydin, B., \& Raven, S. (2020). Preservice science teachers' informal reasoning about hydroelectric power issue: The effect of attitudes towards socio-scientific issues and media literacy. International Journal of Research in Education and Science, 6(4), 551-567. https://doi.org/10.46328/ijres.v6i4.1204

Nassaji, H. (2015). Qualitative and descriptive research: Data type versus data analysis. Language Teaching Research, 19(2), 129-132.

Nielsen, J. A. (2020). Teachers and socioscientific issues-An overview of recent empirical research. In M. Evagorou, J.A. Nielsen \& J. Dillon (Eds). Science teacher education for responsible citizenship. Towards a pedagogy for relevance through socioscientific issues (pp. 13-20). Springer.

Ozturk, N., \& Yilmaz-Tuzun, O. (2017). Preservice science teachers' epistemological beliefs and informal reasoning regarding socioscientific issues. Research in Science Education, 47(6), 1275-1304. https://doi.org/10.1007/s11165-016-9548-4

Öztürk, S., \& Leblebicioğlu, G. (2015). Sosyobilimsel bir konu olan hidroelektrik santraller hakkında karar verirlirken kullanılan irdeleme şekillerinin incelenmesi. Necatibey Ĕ̌itim Fakültesi Elektronik Fen ve Matematik Ĕ̈itimi Dergisi, 9(2), 1-33.

Patronis, T., Potari, D., \& Spiliotopoulou, V. (1999). Students' argumentation in decision-making on a socioscienti c issue: Implications for teaching. International Journal of Science Education, 21, 745-754.

Pehlivanlar, S. (2019). Fen bilgisi ve sınıf ögretmen adaylarının yerel, ulusal ve küresel sosyobilimsel konular hakkındaki informal muhakemeleri [Preservice elementary and science teachers' informal reasoning about local, national, global socioscientific issues]. (Unpublished master's thesis). Recep Tayyip Erdogan University.

Sadler, T. D., Barab, S. A., \& Scott, B. (2007). What do students gain by engaging in socioscientific inquiry? Research in Science Education, 37(4), 371-391.

Sadler, T. D. (2004). Informal reasoning regarding socioscientific issues: A critical review of research. Journal of Research in Science Teaching, 41(5), 513-536. https://doi.org/10.1002/tea.20009

Sadler, T. D., \& Zeidler, D. L. (2004). The morality of socioscientific issues: construal and resolution of genetic engineering dilemmas. Science Education, 88(1), 4-27. https://doi.org/10.1002/sce.10101

Sadler, T. D., \& Zeidler, D. L. (2005). Patterns of informal reasoning in the context of socioscientific decision making. Journal of Research in Science Teaching, 42(1), 112-138. https://doi.org/10.1002/tea.20042

Sakschewski, M., Eggert, S., Schneider, S., \& Bögeholz, S. (2014). Students' socioscientific reasoning and decision-making on energy-related issues - development of a measurement instrument. International Journal of Science Education, 36(February 2015), 2291-2313. https://doi.org/10.1080/09500693.2014.920550

Sampson, V., Enderle, P., \& Grooms, J. (2013). Argumentation in science education: Helping students understand the nature of scientific argumentation so they can meet the new science standards. The Science Teacher, 80(5), 30-33.

Shaw, V. F. (1996). The cognitive processes in informal reasoning. Thinking and Reasoning, 2(1), 51-80.

Simonneaux, L. (2001). Role-play or debate to promote students' argumentation and justification on an issue in animal transgenesis. International Journal of Science Education, 23(9), 903-927. https://doi.org/10.1080/09500690010016076

Stegmann, K., Wecker, C., Weinberger, A., \& Fischer, F. (2011). Collaborative argumentation and cognitive elaboration in a computer-supported collaborative learning environment. Instructional Science, 40(2), 297323. https://doi.org/10.1007/s11251-011-9174-5

Tabachnick, B. G., \& Fidell, L. S. (2013). Using multivariate statistics. Pearson.

The Jamovi Project. (2019). jamovi. [Computer Software]. Retrieved from https://www.jamovi.org.

Topçu, M. S., Sadler, T. D., \& Yilmaz-Tuzun, O. (2010). Preservice science teachers' informal reasoning about socioscientific issues: The influence of issue context. International Journal of Science Education, 32(18), 2475-2495. https://doi.org/10.1080/09500690903524779

Topçu, M. S., Yılmaz-Tüzün, Ö., \& Sadler, T. D. (2011). Turkish preservice science teachers’ informal reasoning regarding socioscientific issues and the factors influencing their informal reasoning. Journal of Science Teacher Education, 22(4), 313-332. https://doi.org/10.1007/s10972-010-9221-0 
Wiyarsi, A., \& Çalık, M. (2019). Revisiting the scientific habits of mind scale for socio-scientific issues in the Indonesian context. International Journal of Science Education, 41(17), 2430-2447. https://doi.org/10.1080/09500693.2019.1683912

Wu, Y.-T. (2013). University students' knowledge structures and informal reasoning on the use of genetically odified foods: Multidimensional analyses. Research in Science Education, 43(5), 1873-1890. https://doi.org/10.1007/s11165-012-9343-9

Yangın, S., Geçit, Y., \& Delihasan, S. (2012). Öğretmen adaylarının hidroelektrik santralleri konusundaki görüşleri [The views of student teachers about hydroelectric plants]. Marmara Coğrafya Dergisi, 26, 124146.

Yıldırım, A., \& Şimşek, H. (2006). Sosyal bilimlerde nitel araştırma yöntemleri [Qualitative research methods in social sciences] $\left(6^{\text {th }}\right.$ ed. $)$. Seçkin.

Zeidler, D. L., Sadler, T. D., Simmons, M. L., \& Howes, E. V. (2005). Beyond STS: A research-based framework for socioscientific issues education. Science Education, 89(3), 357-377. https://doi.org/10.1002/sce.20048

Zohar, A., \& Nemet, F. (2002). Fostering students' knowledge and argumentation skills through dilemmas in human genetics. Journal of Research in Science Teaching, 39(1), 35-62. https://doi.org/10.1002/tea.10008 


\section{APPENDIX}

\section{Hydroelectric Power Plant Scenario}

Instruction: This form has been created to determine your informal reasoning on $\mathrm{HePP}$, which is a socioscientific issue. Please read the preliminary information on the first page and answer the questions on the second page.

Choose the city that you are currently studying in.

\begin{tabular}{|l|l|l|l|l|}
\hline A & B & C & D & E \\
\hline
\end{tabular}

Do you support the establishment of hydroelectric power plants in the city where you are currently studying? (Please choose one)

\begin{tabular}{|l|l|}
\hline Yes & No \\
\hline
\end{tabular}

If your views were asked about the establishment of hydroelectric power plants, would you decide with your intuition, or would you make your decision by considering the evidence regarding this issue? (Please tick one)

\begin{tabular}{|l|l|}
\hline Intuition & Evidence-based \\
\hline
\end{tabular}

Hydroelectric power plants (HEPP) are energy generation systems installed on or near a river. Some of the water in the river bed is transported up to the HEPP through big pipes. When water is taken from the river bed, enough water is left behind to ensure the survival of the living things. This water is called life-water. There are channels between the water reserved for the HEPP and the life-water that will allow fish to pass. The electrical energy obtained from HEPPs significantly meets the country's needs and provides economic income to the country. Since it is renewable energy in the long term and does not emit any chemical waste or radiation to the environment and air, HEPPs that provide clean energy have become increasingly attractive in the Eastern Black Sea region and their number has increased.

On the other hand, HEPP have some damages to nature. It is a problem frequently expressed by the local people that the life-water released to the stream in the region where HEPP is established is insufficient, therefore the stream bed dries up and fish and other living creatures disappear. Taking the water in the stream into the pipes in the region where the HEPP is established, destroys the breeding areas of the fish and restricts the migration movements in the water. With the withdrawal of the water in the stream bed, the plant species in the region dry up and disappear, so the productivity in beekeeping, livestock, and agricultural activities decreases. In addition, it is observed that there are anomalies in microclimate characteristics due to the decrease of water in the stream.

Write the answers to the questions below in the blank spaces below. You can use additional paper if needed.

- Do you agree with the idea that HePP should be built in the city where you are studying? Why?

- If you were trying to convince a friend of the idea of building HePP in the city where you studied, what other reasons could you provide?

- What views can your friend, who disagrees with you about the construction of HePP in the city where you are studying, put forward on this issue?

- In answering this question, you stated the arguments your opponents might have put forward. With what ideas would you defend your stand against these arguments? 


\section{TÜRKÇE GENIŞLETILMIŞ ÖZET}

Uzun y1llardan beri fen eğitiminin en önemli amaçlarından biri öğrencilerin karmaşık yaşam problemleri hakkında bilgilendirilmiș karar vermeleri için gerekli bilgi ve becerileri edinmesi olarak tanımlanmıştır (Sakschewski vd., 2014). Sosyobilimsel konuların öğretimi öğrencilerin bu karmaşık konuların ahlaki ve etik yönlerinin de göz önünde bulundurularak karar verme süreçlerine katılımlarını sağlamak için bir bağlam olarak kullanılmaktadır (Chowdhury, 2016; Sadler ve Zeidler, 2004). Bilimsel düşünme alışkanlıkları ise bireylerin bilimsel bilgiye ulaşma süreçlerinde sahip olmaları geren tutumları içermektedir (Gauld, 2005). Bilimsel düşünme alışkanlıklarından şüphecilik, mantıksallık, nesnellik, argümanlara güvenmeme ve inancın askıya alınması sosyobilimsel konularda karar verme süreçlerinde kullanılan temel bileşenlerdir (Çalık ve Coll, 2011).

Sosyobilimsel konularda karar verme süreçlerinde bireyler informal muhakemelerini kullanmaktadır (Shaw, 1996). İnformal muhakeme süreçlerinde bireylerin konuyla ilgili bilgiye ulaşmaları için araştırma süreçlerine dahil olmaları, bilimsel bilgilere ulaşmaları ve sonucunda bilgilendirilmiş kararlar vermeleri için bireyler bilimsel düşünme alışkanlıklarını kullanmalıdır (Gauld, 1982). Bu nedenle bilimsel düşünme alışkanlıkları informal muhakeme yoluyla sosyobilimsel konularda karar verme için önemli rol oynamaktadır (Wiyarsi ve Çalık, 2019).

İnformal muhakeme ve bilimsel düşünme alışkanlıkları arasındaki bu ilişki teorik olarak ortaya koyulmuş (Çalık ve Coll, 2012; Çalık ve Karataş, 2019), programda önemine vurgu yapılmış (Milli Eğitim Bakanlığı [MEB], 2018) olmasına rağmen konuya ilişkin emprik kanıtlar az sayıdadır. Öğretmenler öğrencilerinin karar verme süreçlerini etkiledikleri için (Çetin vd., 2014) öğretmen eğitiminde de önemli bir yere sahiptir. Böylelikle sosyobilimsel konularda bilimsel düşünme alışkanlıkları göz önünde bulundurularak karar verme becerilerinin geliştirilmesi için dersler, konu bağlamları ve öğretmenler için gerekli yardımlar hazırlanabilir (Topçu vd., 2011). Bu nedenle bu araştırmanın amacı, hidroelektrik santraller konusu bağlamında fen bilimleri öğretmen adaylarının informal muhakemelerinin ve bilimsel düşünme alışkanlıklarının incelenmesidir.

Araştırmanın katılımcıları Doğu Karadeniz bölgesinde hidroelektrik santrallerinin en yoğun olduğu toplam 4 farklı üniversitede fen bilgisi öğretmenliği programlarında öğrenim gören 587 (470 kadın, 117 erkek) fen bilgisi öğretmen adayıdır. Araştırmada betimsel araştırma yöntemi kullanılmıştır (Nassaji ,2015). Araştırmada iki adet veri toplama aracı kullanılmıştır. Birincisi hidroelektrik santrallere yönelik araştırmacılar tarafından hazırlanan açık uçlu soru formudur. Soru formunun birinci kısmında hidroelektrik santrallerin ne olduğu, çalışma prensibi, pozitif ve negatif yönlerine yönelik bilgi verilmiştir. Soru formunun ikinci kısmında ise katılımcıların informal muhakemelerini açı̆̆a çıkarmak üzere 4 adet açık uçlu soru sorulmuştur. İkincisi Çalık ve Coll (2012) tarafından geliştirilen ve 32 maddeden oluşan dörtlü Likert tipindeki bilimsel düşünme alışkanlıkları ölçeğidir.

Açık uçlu soru formunun analizi içerik analiz yöntemiyle yapılmıştır (Yıldırım ve Şimşek, 2006). Katılımcıların sorulara verdikleri yanıtlardaki geçerli nedenler sayılarak kodlanmıştır. Ayrıca informal muhakeme modlarını belirlemeye yönelik sorulara verilen cevaplar içerik analizi kullanılarak analiz edilmiştir. Cevapların gerekçelendirilmesi sırasında katılımcının kaç farklı bakış açısına sahip olduğu ve bu bakış açılarının neler olduğu belirlenmiştir. Analizin güvenirliği için ilk 50 soru formu araştırmacılar tarafından ayrı ayrı kodlanmıştır. Kodlayıcılar arası güvenirlik katsayısı (Miles ve Huberman, 1994) informal akıl yürütmenin kalitesi için .96, muhakeme modları için birinci soru için .88 ve ikinci soru için .90 olarak hesaplanmıştır. Kodlayıcılar anlaşmazlıkları tartışmak için bir araya gelmiştir. Kodlamanın geri kalanı ilk yazar tarafından tamamlanmıştır.

Nicel verilerin analizinde Jamovi programı kullanılmıştır. Öncelikle ölçeğin Cronbach alfa güvenirlik katsayısı hesaplanmıştır. Daha sonra Bilimsel Düşünme Alışkanlıkları Ölçeği’nden elde edilen toplam puana göre bilimsel düşünme alışkanlıkları-yüksek ve bilimsel düşünme alışkanlıkları-düşük olmak 
üzere iki grup belirlenmiştir. Toplam bilimsel düşünme alışkanlıkları ortalama puanı 2,5 (orta nokta) ve üzeri bilimsel düşünme alışkanlıkları-yüksek, 2,5'in altı bilimsel düşünme alışkanlıkları-düşük olarak tanımlanmıştır. Normallik değerleri için basıklık ve çarpıklık değerleri hesaplanmıştır. Bilimsel Düşünme Alışkanlıkları ve informal akıl yürütme biçimleri ile SHOM ve informal muhakeme kalitesi arasındaki ilişkiyi belirlemek için bağımsız örneklemler $t$ testi kullanılmıştır.

İnformal muhakeme modları incelendiğinde ekoloji, bilimsel/teknolojik, ekonomik, politik ve sosyal olmak üzere toplam 5 muhakeme modu tespit edilmiştir. Katılımcıların \%65'i üç ve daha fazla informal muhakeme modunu kullanmıştır. Katılımcıların \%92'si ise birden fazla muhakeme modunu bir arada, farklı kombinasyonlarda kullanmıştır. Ortalama olarak, katılımcılar muhakemelerinde yaklaşık iki ekoloji odaklı gerekçe kullanmış ve bunu bilimsel/teknolojik odaklı muhakeme modları izlemiştir. En az kullanılan informal muhakeme modu sosyal odaklı muhakemedir. Sonuçlar, destekleyici argümanlar için maksimum gerekçelerin sağlandığını göstermiştir. Katılımcılar tarafindan sağlanan karşı argüman sayısı ise en az gerekçeye sahiptir.

Bilimsel Düşünme Alışkanlıkları Ölçeği'nin Cronbach alfa güvenirlik değeri 0.657'dir. Benzer çalışmalarda da benzer sonuçlara ulaşılmıştır (Güven, 2017). Sonuçlar, 174 öğretmen adayının bilimsel düşünme alışkanlıkları puanının yüksek, 413'ünün bilimsel düşünme alışkanlıkları puanının düşük olduğunu göstermiş̧ir.İnformal muhakeme kalitesi ile bilimsel düşünme alışkanlıkları arasındaki ilişki incelendiğinde, yüksek bilimsel düşünme alışkanlıkları grubunun informal akıl yürütme kalitesi, düşük bilimsel düşünme alışkanlıkları grubuna göre daha yüksektir. Ancak bilimsel düşünme alışkanlıkları puanı yüksek olan grup ile düşük bilimsel düşünme alışkanlıkları puanına sahip grubun informal muhakeme modu puan ortalamaları arasında anlamlı bir fark bulunmamıştır ( $\mathrm{p}>0.05)$. Bu sonuca göre öğretmen adaylarının bilimsel düşünme alışkanlıkları ile informal akıl yürütme biçimleri arasında istatistiksel olarak anlamlı bir ilişkinin olmadığı görülmüştür.

Çalışmanın sonuçlarından yola çıkarak öğretmen eğitimi için önerilerde bulunulmuştur. Öğretmen adaylarının çok boyutlu düşünmeleri ve sosyobilimsel konuları farklı boyutlardan değerlendirmeleri için rol oynama, bilgisayar destekli işbirlikli öğrenme ortamları gibi yaklaşımlar kullanılabilir. Konuların sosyal boyutlarının değerlendirilmesi için öğretmen adaylarının failliklerinin arttırılmasına yönelik olarak etkinlikler yapılabilir. Karşıt argümanların kullanımını artırmak ve böylece informal muhakeme kalitesini artırmak için öğretmen adaylarına bilgi aramada şüpheci olmaları öğretilmelidir.

İnformal akıl yürütme bağlama bağlı olduğundan (Atasoy vd., 2019), gelecekteki çalışmalar bu ilişkiyi farklı bağlamlarda tanımlamaya odaklanabilir. İkinci olarak, araştırma bilimsel düşünme alışkanlıkları alt faktörlerinin informal muhakemeyi nasıl yordadığını araştırmak yerine yalnızca fen bilgisi öğretmen adaylarının bilimsel düşünme alışkanlıkları kalitesine odaklanmıştır. Bu nedenle, gelecekteki çalışmalar böyle bir ilişkiyi araştırabilir. Üçüncüsü, kullanılan bilimsel düşünme alışkanlıkları ölçeğinin farklı sosyobilimsel konulara ilişkin soruları mevcuttur. Belirli bir sosyobilimsel konu bağlamı için bilimsel düşünme alışkanlıkları ölçekleri geliştirilebilir ve doğrulanabilir. 